\title{
Reading Psalms, and other urban poems, in a fractured city
}

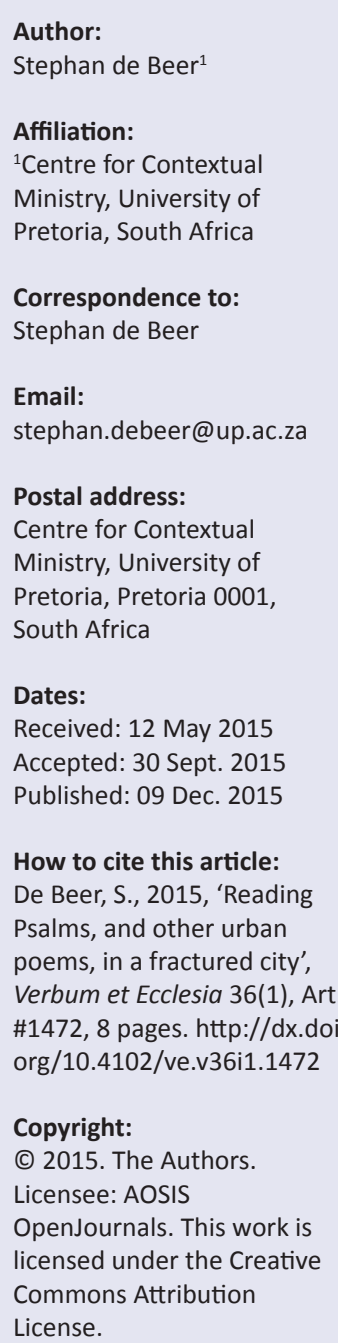

This article was an attempt to (re-)read Psalms in the context of fractured cities, marked by socio-economic inequalities, woundedness, migration and exclusion. It explored urban motifs in selected psalms and considered their possible meanings in relation to both the socio-cultural contexts in which they were written but also how they could be read and understood today. It proposed the Psalms as urban poetry, and considered poems of praise, lament and resistance. It brought the Psalms into conversation both with 'remixed' psalms and also with other urban poems. A 'remix' is a technical term usually associated with altering, adding or changing songs or music into a new version more appropriate or suitable for a new context. It is essentially a genre that emerged from within urban popular culture. Finally, I suggested that an understanding of the Psalms as urban poetry of praise, lament and resistance, in conversation with other urban poems, can serve as a resource to unshackle our faith from the temple, from one city, or from human institutions, evoking a daring new imagination for a new people, new city and new creation.

Intradisciplinary and/or interdisciplinary implications: The article explores contextual readings of the Psalms as urban poetry, and retrieves other urban poems from different genres, both in order to inform urban theological discourse and contextual theological reflections on the fractured city.

\section{Introduction}

A central motif in the book of Psalms is the city of Jerusalem (cf. Ahn 2011:76-82). I would therefore like to suggest that the poetry of praise, lament and resistance found in the Psalms, often in relation to Jerusalem, can be considered an anthology of urban poetry, longing for a return to Jerusalem from exile, but also longing for the rebuilding of a city in ruins; indeed, a fractured city.

Cities throughout the ages have evoked poetic expression: from Jerusalem to Babylon, from Rome to New York. South African poets, from Ingrid Jonker to Wally Mongane Serote, sought to articulate and locate urban cries. In contemporary urban culture it is not different and the bestknown form of such poetry, mostly more profane than the Psalms of the Hebrew Scripture, is found in rap and hip-hop artists essentially being poets of the city.

There are certain questions underlying this article: How does the city feature in the Psalms? How do we read the Psalms in a city that is deeply fractured? How can the Psalms - as urban poems of praise, lament and resistance - inform, disrupt or challenge, both people of faith and churches, but also those with power and those without? How can the Psalms help us understand contemporary urban poems, and how can contemporary urban poetry help us understand the Psalms?

\section{The city in Psalms}

Psalm $84^{1}$ is one of the 'Songs of Zion' which, according to Walter Brueggemann, serves to legitimise Zion-Jerusalem as the epicentre wherein YHWH dwells permanently:

How lovely is your dwelling place,

O LORD Almighty! ...

${ }^{3}$ Even the sparrow has found a home,

and the swallow a nest for herself,

where she may have her young.

The security of the people of Jerusalem was to be found in the fact that God made the city God's dwelling place. In Psalm 125:2 God surrounds his people and makes them be safe:

As the mountains surround Jerusalem,

so the LORD surrounds his people

both now and forevermore. 
We find the same in Psalm 46:4-8:

There is a river whose streams make glad the city of God, the holy place where the Most High dwells.

${ }^{5}$ God is within her, she will not fall;

God will help her at break of day.

${ }^{6}$ Nations are in uproar, kingdoms fall;

he lifts his voice, the earth melts.

${ }^{7}$ The Lord Almighty is with us;

the God of Jacob is our fortress.

${ }^{8}$ Come and see what the Lord has done,

the desolations he has brought on the earth.

For God chose the city in Psalm 132:13-14:

For the LORD has chosen Zion,

he has desired it for his dwelling, saying,

${ }^{14}$ ‘ $T$ This is my resting place for ever and ever;

here I will sit enthroned, for I have desired it.

And in Psalm 122 the poet prays for the city:

${ }^{6}$ Pray for the peace of Jerusalem:

'May those who love you be secure.

${ }^{7}$ May there be peace within your walls

and security within your citadels.'

${ }^{8}$ For the sake of my family and friends,

I will say, 'Peace be within you.'

${ }^{9}$ For the sake of the house of the LonD our God,

I will seek your prosperity.

However, Brueggemann (2001:39) also identifies a tension: the temple, as symbol of God's urban dwelling place, on the one hand forms 'part of the urban-political-economic establishment', but on the other hand should be a place for 'the practice of alternative imagination'. He speaks of the way in which hope has often shifted from YHWH to human institutions, such as the temple in Jerusalem, now 'capturing' God in the temple, appropriating God for ourselves, or, as Brueggemann says, there is 'a propensity in religion to want to domesticate the Lord's presence and reduce God to a safe fetish' (Brueggemann 2001:39). He carries on to say: ' $[i] \mathrm{t}$ is the temptation of religion to have God only with us'.

Throughout the ages the Christian church has too often been closely identified with the urban-political-economic establishment, instead of being a place of a prophetic, alternative imagination. City centre churches of mainline traditions in Pretoria, South Africa changed from places of power in apartheid times (1948-1994) with only glimpses of an alternative prophetic praxis in one or two churches, to vulnerable inner city churches at the turn of the previous century (1995-2005) - seeking deliberately to embody the household of God in all of its diversity in a post-apartheid city - to, once again today, in many cases, becoming places of power closely related to the new political-economic establishment in post-apartheid times; once again too often lacking the ability to offer an alternative imagination. There is a close identification of city, temple and power, co-opting God and subduing the poor.
This could be said of the church generally, where people shift their trust in God to trust in a fallible and temporary human institution - whether temple, state or market - which then, when the institution falters, shatters our faith.

And yet, God, already in the Psalms but also elsewhere in the Hebrew and New Testament Scriptures, subverts the attempt of people to co-opt God for their own city, or to elevate the temple of Jerusalem above God. In Psalm 127:1 there is this stark reminder:

Unless the Lord builds the house,

the builders labour in vain.

Unless the LoRD watches over the city,

the guards stand watch in vain.

Or Kritzinger's (2008:337-338) creative liturgical remix of Psalm 121, which Derrick Mashau (2014) took up in his inaugural lecture entitled 'Reimagining mission in the public square: engaging hills and valleys in the African city of Tshwane':

We lift up our eyes to the hills,

to the high places in and around Pretoria;

Where does our help come from?

Does our help come from Meintjieskop, from the Union Buildings, centre of political power?

Does our help come from Thaba Tshwane, from the National Defence Force, centre of military power?

Does our help come from the high building of the Reserve Bank, centre of economic power?

Does our help come from the high buildings of Unisa or the University of Pretoria, centres of intellectual power?

Our help comes from the LORD, who made heaven and earth.

In the broader Hebrew Scripture and in the New Testament it becomes clear that God's concern goes way beyond Jerusalem, stretching to Nineveh and Babylon, to Rome, Corinth, Ephesus, and indeed, today, to the rest of the world. There seems to always be a tension between a God co-opted to the temple in Jerusalem, or an establishment-religion, and the free God who is embracing the temples and public places of Jerusalem and other cities across the known world.

Of course, there is another city too in the Psalms, the city of Babylon, a place of exile for God's people. It is from within its walls that the exiles are lamenting their fate, are longing for Jerusalem, for the city of God, and protesting the very city that took them into exile. We hear these cries in Psalm 137:

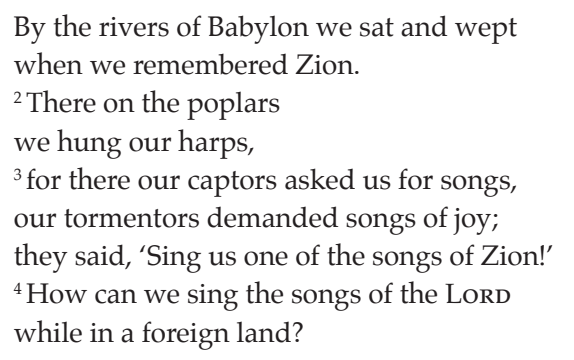

And yet, in Jeremiah 29, we hear the surprising response of God to their lament, in deep contrast to their desired return, suggesting instead that they make Babylon their home; that 
they raise families and plant gardens there; that they work for the shalom of the city to which they have been taken as captives; that they pray for this hostile place. Urban missiologists have always embraced Jeremiah 29:4-7 as an urban mission text, suggesting hard and hostile places as domains for partnering with God in working for shalom (cf. Linthicum 1991:145-149; Bakke 1997:84-88).

Whereas in Psalm 137 God's people struggle to sing their known songs about God's dwelling place in a modern city resembling oppression, in Jeremiah God's invitation is precisely to subvert confining the dwelling place to Zion, in the narrowest sense, or Jerusalem, and to find God in what was to them a hostile place.

The secure God-city of Jerusalem becomes the city Jesus cries over in Luke 13:34:

Jerusalem, Jerusalem, you who kill the prophets and stone those sent to you, how often I have longed to gather your children together, as a hen gathers her chicks under her wings, and you were not willing.

The very temple establishment in Jerusalem now backs the political leaders to violate Jesus. The dwelling place of God is the place that crucifies Jesus as an outcast outside its gates. It is here that Stephen and his friends are killed, and, according to the New Testament scholar Dieter Georgi (2005:59), God's city became a city of death-dealing, the Hellenist followers of Jesus fled and created expressions of the Jesus movement across the known world. They did not assign the same eschatological importance to Jerusalem, and the Jesus-community migrated beyond the confines of this city: For them, Jerusalem became a city among other cities ... They demanded the Hellenistic urban society for Jesus, for the kurios of the world (Georgi 2005:60).

Many of the Psalms are cultic psalms written for public worship in the city. Although some scholars regard them as the poetry of individuals expressing their own faith, most scholars regard them as emerging from within the communal experience as expressions of shared faith.

\section{The fractured city}

We live in an increasingly fractured city. Ours, as almost every city in the world today, are tales of many, and divided, cities. In 'Tale of three cities' rapper Tumi Molekane (2010) speaks of Johannesburg:

City of Lights where life's miniaturized

where the truths sit in disguise So what you willing to eye? Fit in or die

The chill up the spine you feel the silly headlines reveal

The thrill of denial is ill it's unreal, belief comes in appeal

The place of gold, the end of road

for broken souls

The green-light-GO for street-smart folks before they go hard The people that claim, the weak that remain, speaking the same lingo

But still though, they are at odds trying to even the plains The big cribs, the small shacks, the street-kids, the mall-rats
The schemes that fall flat, the dreams for more cash, we living that

White phobia the big fences, the black moguls with the big Benz's The currency that cleansed this, subtle racism mixed-couples Race-killings, big scuffles hate lives between that 'us and they' shit.

The fractured, divided nature of the city and its surrounding villages is depicted also in Psalm 10:8-11:

${ }^{8} \mathrm{He}$ lies in wait near the villages; from ambush he murders the innocent, watching in secret for his victims. ${ }^{9} \mathrm{He}$ lies in wait like a lion in cover; he lies in wait to catch the helpless; he catches the helpless and drags them off in his net. ${ }^{10} \mathrm{His}$ victims are crushed, they collapse; they fall under his strength. ${ }^{11} \mathrm{He}$ says to himself, 'God has forgotten; he covers his face and never sees.'

This passage, as Molekane's poetry, speaks of a fractured city, a fractured people; it speaks of 'us' and 'them' instead of the 'new community'; it raises issues of systemic injustice and lack of accountability, which then result in victims versus oppressors; afflicted versus evil; memory versus forgetfulness. I think of market forces crushing innocent victims and saying to itself: 'God has forgotten; he covers his face and never sees'. I think of the way in which the market has replaced the temple as abode of God, as God. And theology and church seem unable to discern the evil distortions that made God into our project.

Sampie Terreblance (2014:142) suggests that the continuation of white elitism and white corporatism and the creation of black elitism, since 1994, have contributed to the increasing inequalities over the past 20 years. In 2008 the richest 10 million South Africans earned 75\% of the total income of the country, whilst the poorest 20 million earned only $8 \%$ of the total income. In addition, says Terreblanche (2014:143), if only $5 \%$ of the income of the richest $20 \%$ of the population was transferred to the poor, the rich would lose only $5 \%$ of their income, but it would increase the income of the poorest with $60 \%$ ! But this is not happening!

These inequalities are reflected in cities and towns across the South African landscape, and also in the City of Tshwane. It is reflected in the way informal settlements and gated communities exist side by side. Homelessness is on the increase not just in the traditional catch-basin of the city centre and surrounding inner city neighbourhoods, but under city bridges, on road reserves, next to rivers, in city parks, and in the vicinity of many construction sites. The city budget makes provision for the renovation of the City Hall with offices for the Executive Mayor and his staff of 40 people, to an amount of R40 million in the 2014 financial year (Pretoria News 18 August2014), whilst there is only R1.5 million made available to refurbish the city's only overnight shelter - in a city with reportedly 5000 street homeless people, excluding the thousands of people living in informal settlements.

Terreblanche (2014:134) describes how consecutive governments since 1986 have failed to provide infrastructure in informal settlements, despite the massive migration into cities and towns. The city is fractured along economic, racial, national and gender lines. The Gauteng City-Region 
Observatory's research (GCRO 2014) shows how only 22\% of the people in Tshwane trust their neighbours. Just over a month ago Somali shopkeepers were driven out of Mamelodi as a result of xenophobia. One of the biggest issue the Psychology Clinic of the University of Pretoria has to deal with at its clinic in Mamelodi is the reality of child rape (cf. Blokland 2014:182). A generation of children are violated or have to bring themselves up in child-headed households on the fringes of the city - in Stinkwater and Hammanskraal, in Refilwe and Olievenhoutbosch.

In Psalm 68:5-6 we hear good news for some of the most vulnerable people in our city:

A father to the fatherless, a defender of widows, is God in his holy dwelling.

God sets the lonely in families; he leads out the prisoners with singing,

but the rebellious live in a sun-scorched land.

Is God's embrace in this text only meant for children orphaned as a result of war against Jerusalem, or could it also apply to orphans, vulnerable children, and at-risk women, in our and other cities, today?

Perhaps it is important to understand that the city of Jerusalem, as depicted in the Psalms, was itself a fractured city. Some psalms express the cries of the exiled in Babylon; others express the homelessness and home-coming of migrants wandering through desert lands; still others are post-exilic psalms mourning the broken walls of the city, yearning for a new day.

Although the city is praised, much of the praise calls into memory a city of the past, because post-exilic Jerusalem is a city in ruins. And yet, herein lies the gift of the poet, praise is evoked amidst ruin, a new imagination despite the destruction.

Psalm 102 speaks of a city in ruins, reminding of Springsteen's song (2002) of the same title, ${ }^{2}$ but also holds the promise of the Lord rebuilding the city, healing the fractures.

Rabbi Gordis (1968:22) speaks of the golden age of Hebrew poetry 'when the returned exiles had to live in the ruins of the old city surrounded by memories of God at work in the past' (Bakke 1997:70). Psalm 107:4-9 speaks of landless and homeless wanderers, finding their way through the desert and wastelands, until they find a city to dwell in. Saunders (2011), in Arrival city, speaks of global urban migration as the greatest migration the world has ever seen. In Psalm 107 the migrant's utter vulnerability is described and upon arrival it is a real home-coming. At least in South African cities, arrival for many migrants means xenophobic hostility or exclusion from full participation in the resources and life of the city. Some argue that migration - both rural-urban and cross-border - might be the greatest challenge of the church

2. Also refer the article of Johann Meylahn (2014). in the city. And yet, by and large the city church is too far removed from the entry points and concentration places of migrants - whether they live in overcrowded hostels in the east of Johannesburg, or in run-down inner city buildings in all our major urban centres - to be moved into solidarity and action.

And yet: in the fractured city 'the Lord is exalted over the nations', says Psalm 113, equally at home with princes and the poor from the dust:

${ }^{5}$ Who is like the LORD our God, the One who sits enthroned on high, ${ }^{6}$ who stoops down to look on the heavens and the earth? ${ }^{7} \mathrm{He}$ raises the poor from the dust and lifts the needy from the ash heap; ${ }^{8}$ he seats them with princes, with the princes of their people. ${ }^{9} \mathrm{He}$ settles the barren woman in her home as a happy mother of children. Praise the LORD.

A homeless scavenger will rejoice in the message of Psalm 113 suggesting that she will be lifted from the ash heap and seated with princes. The princes of the city might take offence at the thought of the poor from the city's garbage dump dining with them, and choose to read this text in a not so literal way.

\section{Reading Psalms in a fractured city}

How do we read the Psalms in such a fractured city? Do we sing psalms of praise more often if we find ourselves living in golf estates, but if we had to live in the informal settlements of Mamelodi x6 we would resort to psalms of lament more often?

Although we have already started to read Psalms in a city of fracture, I would now like to refer specifically to psalms of praise, lament and resistance/re-imagination. Brueggemann (2002) speaks of these as psalms of orientation, disorientation and new orientation. Considering how psalms of praise contributed to early church liturgies and psalms of lament helped to describe the passion of Christ (cf. Evans 2005:551579), the question is how the Psalms can serve as a resource at a common table laid in a fractured city where people from across the divides gather to meet: how can the Psalms offer sustenance and comfort, rebuke and challenge, and the daring imagination of prophetic alternatives?

\section{Poems of praise}

Many of the psalms can be considered poems of praise, locating God rather specifically within the city, praising God and the city of God. Psalm 50:2 makes a close connection between the city and God, in this simple line: 'From Zion, perfect in beauty, God shines forth'.

In Psalm 87 this deep connection between God and the holy city is asserted again:

\footnotetext{
${ }^{2}$ The Lord loves the gates of Zion more than all the other dwellings of Jacob.

${ }^{3}$ Glorious things are said of you,

city of God.
} 
Psalm 46 does the same in verses 4-5:

${ }^{4}$ There is a river whose streams make glad the city of God, the holy place where the Most High dwells.

${ }^{5}$ God is within her, she will not fall;

God will help her at break of day.

The whole of Psalm 48 is an urban poem of praise:

Great is the LORD, and most worthy of praise,

in the city of our God, his holy mountain.

${ }^{2}$ Beautiful in its loftiness,

the joy of the whole earth ...

${ }^{3} \mathrm{God}$ is in her citadels;

he has shown himself to be her fortress.

${ }^{8}$ As we have heard,

so we have seen

in the city of the LoRD Almighty,

in the city of our God:

God makes her secure forever.

${ }^{11}$ Mount Zion rejoices,

the villages of Judah are glad.

\section{Lament poems}

Of particular interest to me in a fractured city are the lament poems: lamenting exile, oppression and exclusion. Broyles (1989:14) suggests that a lament psalm is not lamentation as it does more than bemoan hardship: it seeks change.

The lament usually offers not just a general cry but a specific 'statement of the wrongs suffered', seeking to evoke 'Yahweh to act on the psalmist's behalf' (Broyles 1989:14).

Brueggemann (2002:9-11) speaks of these as psalms of disorientation: disruption of a settled orientation and a state of security and certainty, and entering a state of disarray, dislocation and 'dismantling of the old, known world'. Praise and goodness are now replaced by anger, loss, shame, guilt and resentment. The enemy is the enemy and God is the enemy. Many urban neighbourhoods are in a perpetual state of disarray, with high concentrations of people who are there as a result of displacement.

And yet, in most urban churches and faith communities we are majoring in psalms of praise. Brueggemann (2002:25) suggests that the hymnody focusing on praise, equilibrium and contentment is deceptive of the pain and anguish alive in personal and communal hearts. The gift of the lament poems is that, instead of denial and covering, they allow for everything to be brought to speech (cf. Brueggemann 2002:27); they lead us away from civil and decent temple worship to a place of uttering the unspeakable, the unthinkable (cf. Brueggemann 2002:29); they utter language that is uncensored and ask questions that are politically incorrect, inviting a just and gracious God to participate with us in our suffering.

In the same way as Broyles, Brueggemann (2002) speaks of psalms of lament as psalms indicating that things are not right, that the wrong can no longer be tolerated, that things do not have to stay the same but can be changed, and that God has to come to our rescue to change it.
After the death of Mike Brown - another young AfricanAmerican male killed by a police officer, although he was unarmed - Nicole Symmonds (2014) visited a number of African-American churches on the following Sunday, and recounts how they continued with business as usual, using psalms of praise instead of poems of lament, as if nothing distressing had occurred. Referring to Brueggemann's 'The costly loss of lament' (1986:57-71), she speaks of the absence of lament as shutting out those who have nothing to rejoice about, but also shutting out the why-question: Why do we suffer as we do? Why does God allow it? How much longer do we have to bear this? She suggests that our psalms of praise are like vaccines against the painful realities of our city, and they prevent us from sitting in lament with those who suffer, until we can imagine change (Symmonds 2014).

This would apply to the distress of young black men on the streets of the United States, but also the distress of children being killed in Reiger Park, or informal traders being chased around by Metro Police and prevented from earning an honest living on the streets of Tshwane, or 55 children raped in April of 2013 alone in Mamelodi Township.

Symmonds (2014) says:

Our lament is not a drive-by prayer as part of an order of worship but a sustained time of passionate complaint that can either be addressed to God against our neighbor or addressed to God against God. In doing this we are using responsible faith to engage with the God in whom we have put our trust.

In response to a ban on being homeless in the city of Denver, Ryan Taylor (2012) remixed Psalm 23 into a poem of lament:

The Lord is my Shepherd, I lack nothing. He allows me to lie in green pastures... / ... but rather than rest and restoration a police officer disrupts my sleep saying, 'You can't lie in these green pastures. They're not for you. Pack up your belongings and "move along". Or you will face a fine or imprisonment'. / Thus, I am forcibly provoked to gather my things and move to a far more dangerous place - the valley of the shadow of death - where I will surely be threatened, harassed, fearful... / Who is watching out for me? And by the way ... Where!, Oh Lord, is this so called, 'Table you have prepared for me in the presence of my enemies'?

Our loss of lament is symptomatic of a deeper challenge which Brueggemann (2002:39) frames as our lost capacity 'to think theologically about public issues and public problems'. We lack the language, rituals, prayers, poems, and worship songs to articulate our collective agony, lament or critique at public evil. We do not have the tools of analysis, and those of us belonging to the dominant culture are simply too far removed from the painful experiences outside the city's gate to be moved to lament, and then beyond, to prophetic action.

\section{Poems of resistance}

Lament in the Psalms is not meant for paralysis but gives birth to resistance. Many poems in the Psalmody are resistance poems, naming that which destroys life and confessing a God who is not neutral but siding with the poor, the suffering and the outcast. 
Prayer is a rebellion against the status quo calling on the God who created everything to reconcile all things to himself - the broken people, messed-up relationships and unjust systems to a holistic freedom that restores shalom (Walton 2011).

The disorientation of the lament poems 'evokes robust resistance' (Brueggemann 2002:10). Consider, for example, Psalm 82:

God presides in the great assembly;

he renders judgment among the 'gods':

${ }^{2}$ 'How long will you defend the unjust

and show partiality to the wicked?

${ }^{3}$ Defend the weak and the fatherless;

uphold the cause of the poor and the oppressed.

${ }^{4}$ Rescue the weak and the needy;

deliver them from the hand of the wicked.'

And Psalm 94 (vv. 5-7), which speaks of God's judgement upon oppressive and unaccountable leadership:

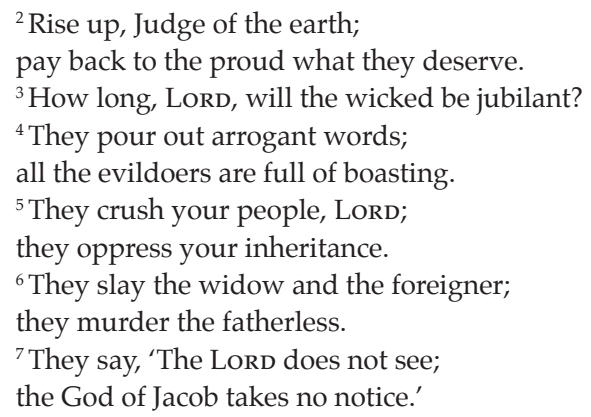

Just when the temple or Jahweh on the throne wants to become complacent, the poet raises questions of justice and equity again and again (cf. Brueggemann 2002:xiv). '[T] he Psalms are profoundly subversive of the dominant culture, which wants to deny and cover over the darkness we are called to enter' (Brueggemann 2002:xii). On the one hand the book of Psalms fulfils 'an imperial function of asserting a wellordered status quo' but it also fulfils 'a subversive function of undermining a well-ordered status quo' (Brueggemann 2002:48), depending on the specific context, intent and use of the psalm in a given situation.

In reflecting upon the National Development Plan, Terreblanche (2014:152) levels critique against what he calls 'fairy tale' objectives of the plan, as a result of its failure to consider 'the structural nature of poverty, joblessness and inequality in our country'. In addition he asks why the churches do not wage an open war on behalf of those who are undeservedly poor and against those who are undeservedly rich (Terreblanche 2014:148).

In a deeply fractured city, the Psalms can fulfil a similar function: to unmask the fairy tale of temple, market and state, to lament and resist structural injustices and spatial exclusions, until a new imagination breaks through of the change we would like to see.

Harvey Cox (1965:114-125) suggested as one of the primary functions of the church in the city to heal urban fractures. The fractured nature of the city cannot be minimised as it is indeed death-dealing in its effects. However, fractures can be healed. In Psalm 147 the Lord is praised for building up Jerusalem, for gathering the exiles, for healing the brokenhearted, for binding up their wounds. This seems to me like an agenda for the urban mission of the church.

\section{Reading other urban poems in fractured cities}

Contemporary urban poems, much like the Psalms, also offer praise, lament and resistance, in response to the fractured cities they find themselves in.

Afrikaans singer Koos du Plessis (1980b) praises 'Pretoria', and in 'Fairy tale of an urban child' ('Sprokie van 'n stadskind'), he evokes, rather melancholically, urban imagery to express the dreams of a city child.

He locates the child in the urban neighbourhoods that spelled exclusion and Fanon's 'living death', reminding me of another poem in Lamentations where it mourns the fact that children die on the corners of the city's streets.

The rapper, Akon (2004), sings of the despair felt by those living in so-called urban ghettoes:

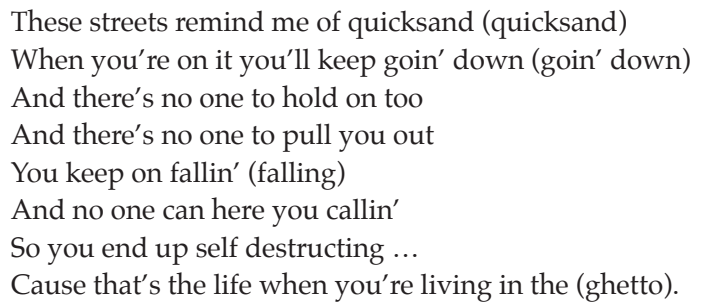

Whilst Mongane Wally Serote (1972) expresses very ambivalent emotions towards Alexandra, his city, his mother, which Maluleke captured in a missiological reflection on urban black townships:

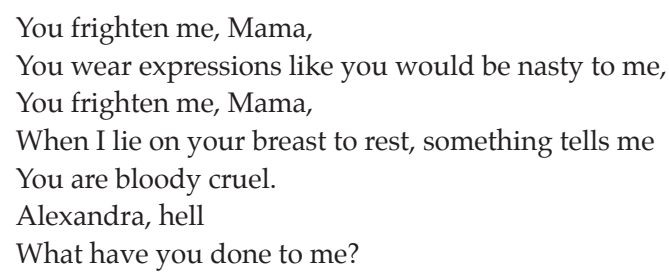

Bu then he goes on:

Alexandra, I love you;
I know
When all these worlds became funny to me
I silently waded back to you
And amid the rubble I lay,
Simple and black.

In the same hard places of self-made houses and run-down buildings, Jeff Burt (2014) finds God squatting:

The Lord is my mentor-I want him to teach.

He tells me to lie down with headphones unplugged.

He leads me into anonymous streets.

He eats when I eat. 
Even though I walk the hardened streets, I have no fear. I don't even carry a rod for comfort.

He likes my cap, that I wear it a little sideways on my head.

Darkness stays late in the valley of the buildings,

comes early. The drunk after dinner I pick up at dawn.

Surely my friends he will make a blessing for me and be kind, and I will be squatting in the projects with him, dropping off his grace, dealing out mercy.

Johannes Kerkorrel and Gereformeerde Blues Band (1989), the alternative Afrikaans rocker, wrote a song entitled, 'Hillbrow'. Being more prophetic than most churches in calling on listeners to 'give your heart to Hillbrow' - a neighbourhood in decline, politically incorrect in those times as a place of refuge for mixed-race couples, the gay and immigrant community, those hiding from the law or finding themselves in drugs, and not understood or embraced by the dominant Christian community - this line in the chorus of the song became like an anthem for those who felt called to embrace changing and hard places in our cities.

Hillbrow itself became a prophetic community leading the way in becoming a changed neighbourhood when all other urban places were still segregated and exclusive. Kerkorrel's song is a poem of praise, lament and resistance: affirming Hillbrow as home to many, lamenting that 'we survive with a hell of a lot of pain in this land', resisting the deathdealing departure and disinvestment from neighbourhoods such as these, and evoking a passionate embrace of exactly such places.

His call to give our hearts to Hillbrow resembles to me the description given in Psalm 102:14. The city is in ruins, and yet, paraphrased from the Afrikaans translation, it says: 'Your servants love every stone of Zion, and they are moved about its ruins'. It speaks of a deep love for their city, for every broken wall and every lost stone, without which a sustained engagement with a fractured city is probably impossible.

\section{Evoking a daring imagination}

I suggest that the Psalms as urban poems of praise, lament and resistance, can serve as a resource to unshackle our faith from the temple, in order for it to fill the whole city; to unshackle our faith from one city, in order for it to embrace all of creation; to unshackle God from our human institutions, in order for God to be God. It can indeed be a resource to evoke a daring imagination in our midst for transforming cities of fracture into the shalom of God.

I conclude by suggesting that this unshackled God is deeply concerned about (1) broken hearts and broken walls, about (2) power and powerlessness and about (3) justice for people, the city and all of creation alike.

\section{Broken hearts and broken walls}

In Psalm 51 the psalmist moves swiftly from personal brokenness to corporate brokenness, and one might further explore the possible connections between the personal and the corporate - in terms of repentance and responsibility when the rebuilding of fractured cities is our agenda. How can we foster private, corporate and public liturgies and actions to embody this concern?:

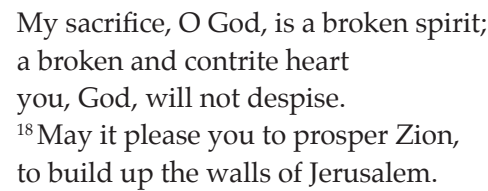

\section{Power and powerlessness}

God is equally concerned about transforming power and the way it works, as well as powerlessness. In the prayer for the king in Psalm 72 this is articulated clearly. How again do we retrieve the Psalms as resource for transforming power and powerlessness?:

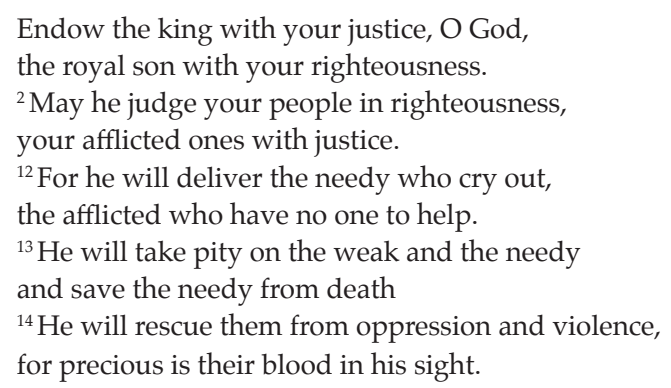

\section{Justice for people, the city and all of creation}

God is concerned with justice in a much fuller sense of the word than we can even imagine. In Psalm 146 this is a resounding concern:

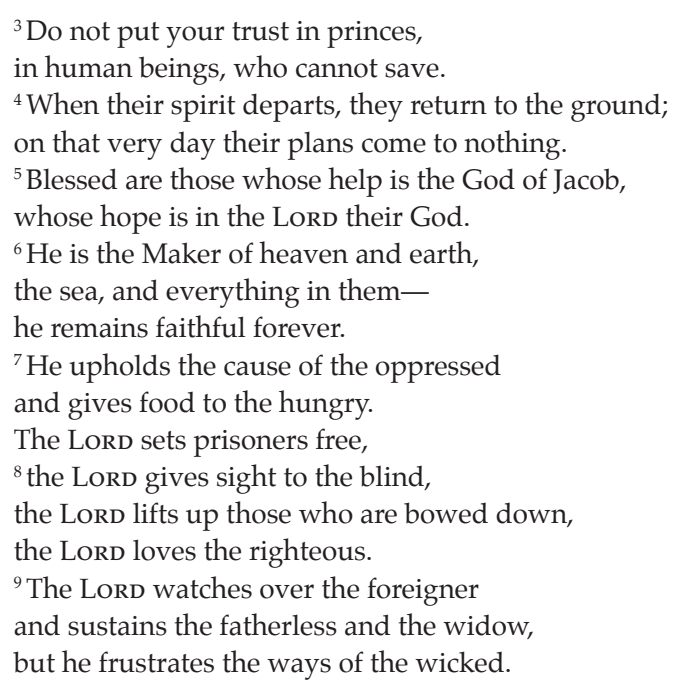

In Psalm 10:15 the poet insists that the Lord 'break[s] the arm of the wicked and evil man, calling him to account for his wickedness that would not be found out'.

And in Psalms 24, 96 and 104 justice for the city is to be considered, now against the backdrop of all creation: the poet is relativising city, market and temple, and embracing all of creation as God's dwelling place, as belonging to God, as being held by God, including the city, and, if all of creation, it means not only Jerusalem but every city on the face of the earth. 
Considering the city and cities of fracture we find ourselves in, we could indeed cry out: 'Why did You not hear our prayers? Where is peace in Jerusalem, in Tshwane? After all this time, have You abandoned us? Where are You in the fractures of our city?'

\section{Acknowledgements Competing interests}

The author declares that he has no financial or personal relationships which may have inappropriately influenced him in writing this article.

\section{References}

Ahn, J.J., 2011, Exile as forced migrations: A sociological, literary, and theological approach on the displacement and resettlement of the Southern Kingdom of Judah, Walter de Gruyter, Berlin.

Akon, 2004, 'Ghetto', on the album Trouble, produced by Pete Rock, SRC/Universal, New York.

Bakke, R., 1997, A theology as big as the city, InterVarsity Press, Downers Grove.

Blokland, L.M.E., 2014, 'Mental health care in Mamelodi: Disadvantaged geographical positioning in a South African township', De Jure 44(2), 175-188.

Burt, J., 2014, 'Three urban Psalms', viewed 19 May 2014, from http:// secondnaturejournal.com/three-urban-psalms

Broyles, C.C., 1989. The conflict of faith and experience in the Psalms: A form-critical and theological study, A\&C Black, Sheffield.

Brueggemann, W., 1986, 'The costly loss of lament', Journal for the Study of the Old Testament 11, 57-71. http://dx.doi.org/10.1177/030908928601103605

Brueggemann, W., 2001, The Bible makes sense, Westminster John Knox Press, Louisville.

Brueggemann, W., 2002, Spirituality of the Psalms, Fortress Press, Minneapolis.

Cox, H., 1965, The secular city, Macmillan, New York.

Du Plessis, K., 1980a, 'Pretoria', on the album Skadu's teen die muur, Incline House, Cape Town.

Du Plessis, K., 1980b, 'Sprokie van 'n stadskind', on the album Skadu's teen die muur, Incline House, Cape Town.

Evans, C.A., 2005, 'Praise and prophecy in the Psalter and in the New Testament', in P.W. Flint \& P.D. Miller (eds.), The Book of Psalms: Composition and reception, pp. 551-580, Brill, Leiden.
Flint, P.W. \& Miller, P.D. (eds.), 2005, The Book of Psalms: Composition and reception, Brill, Leiden.

GCRO, 2014, 'City Benchmarking Quality of Life Survey 2013', Gauteng City-Region Observatory Johannesburg viewed 28 August 2014, from http://www. gcro.ac.za/ sites/default/files/editor uploads/QoL2013_launch/qol_2013_baseline_city report_presentation_launch_14_august_2014.pdf

Georgi, D., 2005, The city in the valley: Biblical interpretation and urban theology, Society of Biblical Literature, Atlanta.

Gordis, R., 1968, Koheleth, the man and his world: A study of Ecclesiastes, Shocken Books, New York.

Kerkorrel, J. \& Gereformeerde Blues Band, 1989, 'Hillbrow', on the album Eet kreef, Shifty Records, Johannesburg.

Kritzinger, J.N.J., 2008, 'Where does our help come from? Psalm 121 in Tshwane', Missionalia 36(2/3), 337-338.

Linthicum, R.C., 1991, City of God, city of Satan, Zondervan, Grand Rapids.

Mashau, T.D., 2014, 'Reimagining mission in the public square: Engaging hills and valleys in the African city of Tshwane', Inaugural lecture at the University of South Africa, 26 June.

Meylahn, J.A., 2014, “"My city of ruins”: A city to come', HTS Teologiese Studies/ Theological Studies 70(3), Art. \#2723, 6 pages. http://dx.doi.org/10.4102/hts. v70i3.2723

Molekane, T., 2010, 'A tale of three cities' (v. 2), on the album ' $n$ Ware verhaal, Copyright Rhythm Records, Published by Bittereinder, Pretoria.

Pretoria News, 2014, 'Renovated City Hall to be "Inspirational"', posted by the Editor, Monday 18 August 2014, viewed 1 September 2014, from http://www. iolproperty.co.za/.roller/news/entry/renovated_pretoria_city_hall

Saunders, D., 2011, Arrival city: The final migration and our next world, Vintage, Toronto.

Serote, M.W., 1972, Yakhal'inkomo, Renoster Books, Johannesburg.

Springsteen, B., 2002, 'My city of ruins', on the album The rising, Produced by Brendan O'Brien, Columbia Records. http://brucespringsteen.net/songs/ my-city-of-ruins.

Symmonds, N., 2014, 'On Mike Brown in church: The importance of sitting in lament', posted 13 August 2014, viewed 28 August 2014, from http://www. urbanfaith.com/2014/08/on-mike-brown-in-church-the-importance-of-sittingin-lament.html

Taylor, R., 2012, 'A lament psalm for Denver's proposed "urban camping ban"', posted 24 April 2012, viewed 21 August 2014, from http://tallmonasticguy.typepad.com/ my_weblog/2012/04/a-lament-psalm-for-denvers-proposed-urban-campingban.html

Terreblanche, S., 2014, Verdeelde land: Hoe die oorgang Suid-Afrika faal, Tafelberg, Kaapstad.

Walton, J., 2011, 'What is "Psalms of freedom"', posted 16 December 2011, viewed 28 August 2014, from http://nycurbanproject.com/2011/12/what-is-psalms-offreedom 